\title{
PAREDES QUE FALAM: A ESCRITA IMAGÉTICA DE LÚCIO CARDOSO EM CRONNICA DA CASA ASSASSINADA
}

Rejane Debbie Fernández Loureiro de Paiva Mestranda em Teoria da Literatura do Programa de Pós-Graduação em Estudos Literários /

\begin{abstract}
RESUMO
Este artigo visa a uma primeira investigação do modo como se articula a configuração espaço-tempo no romance Crônica da casa assassinada, de Lúcio Cardoso, a partir de uma leitura crítica das imagens textuais e visuais, notadamente o esboço feito pelo autor e inserido no início da narrativa.
\end{abstract}

\section{PALAVRAS-CHAVE}

Lúcio Cardoso, esboço, imagens, espaço, tempo

“A pintura é uma poesia silenciosa e a poesia uma pintura que fala.” 1

Nascido em Curvelo em 1912, Lúcio Cardoso debuta na literatura brasileira no começo dos anos 1930. Dono de uma obra plural, introspectiva e cíclica, o controverso escritor transitou por vários gêneros literários. Entretanto, foi consagrado canonicamente por sua obra romanesca, da qual destacamos Crônica da casa assassinada, publicada em $1959^{2}$ e considerada por grande parte da crítica como sua obra-prima.

Seus romances abordam, frequentemente, problemas religiosos e conflitos de consciência, em uma construção estética com fortes inflexões góticas, herdeira tanto da literatura romântica dos séculos 18 e 19 quanto do cinema noir, trazendo em si marcas baudelairianas, traços do Barroco, do Romantismo e do Decadentismo.

Acometido por um enfarte em 1962, cala-se o escritor e ganha vida o pintor Lúcio Cardoso, que, valendo-se de sua mão esquerda, passa a se expressar pela pintura e pelo

\footnotetext{
${ }^{1}$ Plutarco citado por SELIGMANN-SILVA. A escritura da memória: mostrar palavras e narrar imagens, p. 99.

${ }^{2}$ Aqui contemplada em sua edição comemorativa de 40 anos, de 2009.
} 
desenho, através dos quais segue propondo as mesmas questões humanísticas presentes em sua escrita.

Crônica da casa assassinada narra a história dos Meneses, família arruinada do sul de Minas, que, mesmo sem posses, tenta manter a antiga fidalguia. Sua desestruturação evidencia-se quando Valdo, irmão mais novo, traz do Rio de Janeiro sua esposa, mulher jovem e deslumbrante, "um sol visto de todos os lados", 3 que se converte em elemento catalisador do combate entre os irmãos e da consequente derrocada final do núcleo familiar, colocando em questão o próprio ideal de família e sociedade.

A história se dá a conhecer a partir do relato de suas atormentadas personagens, que intercambiam cartas, depoimentos e anotações em diários, numa (re)construção memorialística que busca dar sentido às suas existências e que vão, por esse modo, descerrando portas e desvendando os recantos obscuros da trama, numa sucessão de imagens pouco reveladoras, já que se apresentam constantemente sob uma luz baça, uma vez que "a eletricidade em nossa vila é deficiente”. 4

Segundo Benjamin, “a relação do pretérito com o Agora é dialética, não é de natureza temporal, mas de natureza imagética”. ${ }^{5} \mathrm{O}$ passado vai se materializando no presente através de imagens, que podem ser ativadas por meio de estímulos aos sentidos.

Roland Barthes ${ }^{6}$ afirma que as imagens podem ser lidas, proporcionando-nos várias leituras de uma mesma face. Considerando seu caráter retórico e diante da afirmativa de Alberto Manguel, “(...) las imágenes, como los relatos, nos brindan información”, 7 é que nos propomos buscar "o que há por trás da imagem” ${ }^{8}$ nessa narrativa cardosiana, cuja imagem parece apontar para esse “algo mais” de que nos fala Didi-Huberman. ${ }^{9}$ Portanto, este trabalho tem por objetivo fazer uma leitura crítica do esboço ${ }^{10}$ feito por Lúcio Cardoso - que pode ser observado no início do romance Crônica da casa assassinada - sob a ótica de Barthes e sem perder de vista o paradigma de Manguel, que segue afirmando: "las lecturas críticas han

\footnotetext{
${ }^{3}$ CARDOSO. Crônica da casa assassinada, p. 31.

${ }^{4}$ CARDOSO. Crônica da casa assassinada, p. 45.

${ }^{5}$ Citado por DIDI- HUBERMAN. O que vemos, o que nos olha, p. 182.

${ }^{6}$ BARTHES. A câmara clara: nota sobre a fotografia.

${ }^{7}$ MANGUEL. Leer imágenes. Una historia privada del arte, p. 21.

${ }^{8}$ GUIMARÃES. Imagens da memória: entre o legível e o visível, p. 193.

${ }^{9}$ DIDI- HUBERMAN. O que vemos, o que nos olha.

${ }^{10}$ Esboço anexo no final deste artigo.
} 
acompañado a las imágenes desde el inicio de los tiempos, pero jamás las reproducen, sustituyen o asimilan realmente."11

Sobre a retórica das imagens, tanto visuais quanto textuais, o escritor argentino afirma:

(...) para quienes pueden ver, la existencia transcurre en un contínuo despliegue de imágenes captadas por la vista y que los otros sentidos realzan o atenúan, imágenes cuyo significado (o presunto significado) varía constantemente, con lo que se construye un lenguaje hecho de imágenes traducidas a palabras y de palabras traducidas a imágenes, a través del cual tratamos de captar y comprender nuestra propia existencia. Las imágenes que componen nuestro mundo son símbolos, signos, mensajes y alegorías. (...) Pero, ¿toda imagen permite una lectura? O, por lo menos, ¿podemos crear una lectura para cada imagen? Y, de ser así, ¿cada imagen implica algo cifrado por la simple razón de que se nos aparece, a quienes las vemos, como un sistema cabal de signos y de reglas? ¿Son todas las imágenes susceptibles de ser traducidas a un lenguaje comprensible que revele a quien la vea lo que podríamos llamar su Relato, con erre mayúscula? ${ }^{12}$

Por sua vez, César Guimarães questiona: “(...) O que leva a literatura a mesclar a palavra com a imagem, essa matéria que lhe é estranha, pertencente a outro regime semiótico e que escapa à estrutura binária do signo linguístico? Por que a letra busca a imagem? (...)”.13

Tentando entender a natureza da relação imagem/texto, recorremos a Roland Barthes, que afirma: “aqui [na publicidade] a palavra e a imagem (...) tem uma relação de complementaridade.”"14 Entretanto, no romance do escritor mineiro, a imagem parece constituir-se em uma narrativa iconográfica: o esboço traçado pelo próprio autor e que abre a narrativa parece trazer, plasmado em si, o eixo temático sobre o qual discorre o romance.

O desenho, segundo Barthes, ${ }^{15}$ embora a princípio denotado, é uma mensagem codificada, já que sua realização pressupõe uma escolha prévia dos elementos que serão representados e dos elementos que ficarão fora da representação. Exige também certo domínio da técnica e uma transformação ou uma interpretação, por parte do desenhista, da relação entre os significados e os significantes que este vê e que posteriormente transportará para o suporte. Portanto, “a 'feitura’ de um desenho já é uma conotação”. ${ }^{16}$ Para Peter Burke, ${ }^{17}$ os esboços são mais confiáveis - enquanto testemunhos de evidências históricas - que as

\footnotetext{
${ }^{11}$ MANGUEL. Leer imágenes. Una historia privada del arte, p. 32.

${ }^{12}$ MANGUEL. Leer imágenes. Una historia privada del arte, p. 21-22, grifos nossos.

${ }^{13}$ GUIMARÃES. Imagens da memória: entre o legível e o visível, p. 195.

${ }^{14}$ BARTHES. A retórica das imagens, p. 33.

${ }^{15}$ BARTHES. A retórica das imagens.

${ }^{16}$ BARTHES. A retórica das imagens, p. 36.

${ }^{17}$ BURKE. Testemunha ocular: história e imagem.
} 
pinturas trabalhadas em estúdio, já que nessas últimas podem interferir outras referências exteriores à imagem.

Walter Benjamin afirma que “a língua é o lugar onde é possível encontrar as imagens dialéticas”. ${ }^{18}$ Lúcio Cardoso, fazendo uso de seu talento de pintor para transpor para o texto imagens arrebatadoras, na obra em questão, parece configurar a narrativa na imagem da casa, que em uma relação simbiótica com a família que (des)abriga, dotada de organicidade e impregnada de tempos de memória, se deteriora: "Mas a imagem da casa lacerada, como se fosse um corpo vivo, não me saía mais do pensamento.”19

É a casa, palco dos encontros e desencontros das personagens, que parece desempenhar o papel principal na narrativa, em uma inversão da ordem: personagens feitos de cal e pedra e paredes feitas do sangue e da carne de seus habitantes.

Para Gaston Bachelard, ${ }^{20}$ a casa é um ser privilegiado que, se a considerarmos concomitantemente em sua unidade e em sua complexidade, pode vir a fornecer-nos - de maneira simultânea - imagens dispersas e um corpo de imagens, que, por sua vez, nos "falam” diretamente daqueles que a habitam. Sobre a simbologia da casa no que concerne à memória, o filósofo e poeta francês afirma:

(...) é graças à casa que um grande número de nossas lembranças estão guardadas; e quando a casa se complica um pouco, quando tem um porão e um sótão, cantos e corredores, nossas lembranças têm refúgios cada vez mais bem caracterizados. A eles regressamos durante toda a vida, em nossos devaneios. ${ }^{21}$

Em Crônica da casa assassinada, o autor parece produzir seus efeitos de memória através das imagens da casa, na qual podem ser percebidas "fendas que se abriam nos alicerces da casa, gretando os esteios fortes e bem plantados, disjuntando as pedras da base (...), ${ }^{22}$ e que, povoada de ruínas vivas em franca degradação social e moral, é implacavelmente destruída pelo tempo.

O tempo/gangrena parece corroer igualmente a família e o espaço que a cerca. É possível observar o processo de dissolução - duplamente plasmado na casa e na personagem Nina - na meticulosa narrativa do médico:

\footnotetext{
${ }^{18}$ Citado por DIDI-HUBERMAN. O que vemos, o que nos olha, p. 181.

${ }^{19}$ CARDOSO. Crônica da casa assassinada, p. 242.

${ }^{20}$ BACHELARD. A poética do espaço, p. 28.

${ }^{21}$ BACHELARD. A poética do espaço, p. 28.

${ }^{22}$ CARDOSO. Crônica da casa assassinada, p. 147.
} 
(...) mas a verdade é que de há muito eu pressentia um mal qualquer devorando os alicerces da Chácara. (...) como um corpo gangrenado que se abre ao fluxo dos próprios venenos que traz no sangue. (Ah, esta imagem de gangrena, quantas vezes teria que voltar a ela (...). Gangrena, carne desfeita, arroxeada e sem serventia, por onde o sangue já não circula, e a força se esvai, delatando a pobreza do tecido e essa eloquente miséria da carne humana. Veias em fúria, escravizadas à alucinação de um outro ser oculto e monstruoso que habita a composição final de nossa trama, famélico e desregrado, erguendo ao longo do terreno vencido os esteios escarlates de sua vitória mortal e purulenta). ${ }^{23}$

Lúcio Cardoso, trabalhando as palavras em filigrana, através de descrições minuciosas e até mesmo microscópicas, parece transportar seus leitores ao terreno das sensações.

O espaço narrativo é a chácara dos Meneses, na fictícia cidade de Vila Velha, no sul de Minas Gerais. Podemos propor aqui, seguindo o modelo barthesiano, uma análise da imagem que abre a narrativa: esse esboço contém, claramente, uma mensagem linguística: os nomes de cada recanto do lugar; uma mensagem icônica codificada: um mapa e uma mensagem icônica não codificada.

A- MENSAGEM LINGUÍSTICA: segundo Barthes, “o texto conduz o leitor por entre os significados da imagem, fazendo com que se desvie de alguns e assimile outros (...), ele o teleguia em um sentido escolhido a priori". ${ }^{24}$

Os nomes dos lugares apontados no mapa são absolutamente passíveis de ser encontrados em Minas Gerais, inclusive no Brasil. Entretanto, queremos acreditar que esses nomes, reunidos nessa narrativa, fazem uma composição semântica altamente significativa.

Em uma primeira análise toponímica, é possível perceber a relação íntima do espaço com a atmosfera anímica da trama: Vila Velha (antiquado, retrógrado, detentora de passado); estrada de Queimados (o que está queimado não se recompõe, vira cinza, retorna ao pó); Serra do Baú (baú guarda segredos, depósito de memórias); antiga fazenda: é o passado presentificado plasticamente.

B- MENSAGEM ICONOGRÁFICA CODIFICADA: também chamada por Barthes uma "mensagem suficiente", 25 uma vez que possui pelo menos um sentido no âmbito da identificação com a cena representada. Aqui, é o próprio mapa, facilmente reconhecível através da cultura e que traz em si uma "ausência de sentido, que contém todos os sentidos”. ${ }^{26}$

\footnotetext{
${ }^{23}$ CARDOSO. Crônica da casa assassinada, p. 152-153.

${ }^{24}$ BARTHES. A retórica das imagens, p. 33.

${ }^{25}$ BARTHES. A retórica das imagens, p. 35.

${ }^{26}$ BARTHES. A retórica das imagens, p. 35.
} 
C- MENSAGEM ICONOGRÁFICA NÃO CODIFICADA: o tanque e o regato, representando a bipolaridade: estagnação e fluidez. Há aqui um trânsito entre o próprio e o figurado. O fluido propriamente dito faz interação com o plano metafórico: no regato, tal como o rio de Heráclito, ${ }^{27}$ é o fluir do tempo, a vida que se esvai e sai dos limites da chácara “essa contínua evolução do que somos, do que fazemos e do que sentimos”,28 - ,colocando-se para além do alcance dos Meneses - e no tanque é “esse lago estanque que é a memória”29 ou o tempo contido: água parada, como parada em um tempo de glória que não volta mais, está a família, cristalizada em sua honra e orgulho, que carrega como um distintivo. Elemento primevo à vida, a água, para Jean Chevalier e Alain Gheerbrant, é, na Ásia, “a forma substancial da manifestação, a origem da vida, (...). Fluida, sua tendência é a dissolução, mas homogênea também, ela é igualmente o símbolo da coesão e da coagulação”. ${ }^{30}$

No mapa, pode-se observar, também, a disposição dos vários ambientes da casa, por meio da qual acreditamos ser possível “ler”, en passant, a posição que as personagens ocupam na narrativa: alta na frente, a casa parece reafirmar o seu status senhorial, já que os visitantes precisam ascender pela escada à posição dos Meneses. A preocupação destes com o social pode ser observada no tamanho privilegiado dos espaços sociais. Os quartos estão distribuídos em rígida disposição, ao longo de um corredor (espaço de transição): primeiro, o quarto, ocupado por Demétrio, o chefe da família, defensor da moral e da virtude, o guardião; depois, separado por um banheiro e um cubículo (depositário de trastes inúteis que vão se acumulando ao longo dos anos), o quarto de Valdo, personagem que, incapaz de transgredir as normas familiares, se mantém no meio do embate entre o novo - representado por sua esposa Nina e seu irmão Timóteo - e a tradição, representada ferreamente por Demétrio. Finalmente, refugado para os confins do casarão (portanto, em situação limítrofe) e disposto na parte baixa da moradia, o quarto de Timóteo, o irmão louco e pervertido.

Do alto para o baixo, do começo para o fim, do social para o íntimo, do público para o privado, do visível para o escondido, alojam-se os herdeiros da Chácara, ocupantes de um mesmo lado da moradia. Frente a eles, do outro lado do corredor (ou da vida?), se encontram os quartos de André, filho espúrio de Ana (esposa de Demétrio) - e Alberto (o jardineiro

\footnotetext{
${ }^{27}$ MANGUEL. Leer imágenes. Una historia privada del arte, p. 23-24.

${ }^{28}$ CARDOSO. Crônica da casa assassinada, p. 489.

${ }^{29}$ CARDOSO. Crônica da casa assassinada, p. 489.

${ }^{30}$ CHEVALIER; GHEERBRANT. Dicionário de símbolos, p. 15.
} 
suicida) e de Betty, a empregada de confiança, mediadora do embate entre os irmãos e mensageira de uns e outros.

Para Barthes, a mensagem literal (denotada) funcionaria como suporte da mensagem simbólica (conotada). Na narrativa em questão, encontramos o mapa como suporte onde se inscreve a mensagem simbólica.

Fluidez e estagnação, dissolução e coagulação, morte e vida, finitude e permanência parecem ser o cerne do romance, que a personagem André, em sua primeira carta que abre textualmente o romance, questiona:

Que é o para sempre senão o existir contínuo e líquido de tudo aquilo que é aberto de contingência, que se transforma, evolui e deságua sem cessar?” (...) "eu mesmo, também para sempre, escorreria e passaria” (...) “também escoaria para sempre meu amor” (...). ${ }^{31}$

É possível perceber, aqui, uma coesão entre imagem iconográfica e o campo semântico, que remete ao elemento líquido: a mensagem linguística parece fixar a mensagem do esboço, que, por sua vez, parece reiterar as profundas questões existencialistas tratadas na obra.

Na narrativa, o elemento líquido parece simbolizar o tempo, em sua inexorável passagem ou na vã tentativa de retê-lo: a memória. Seria então "as imagens do tempo esgotado". 32

Maria Madalena Loredo Neta $^{33}$ afirma haver nessa novela cardosiana uma explícita revolta contra a estagnação vital provocada pelo cotidiano limitado e pela rotina, que acabaria por nivelar as pessoas aos objetos. É André quem diz: (...) “todas aquelas paredes me pareciam suadas de um hábito e de uma continuidade de vida que eu ignorava qual fosse.”34

A questão do tempo nessa narrativa parece ser reiterada pela presença das ruínas (vestígios do tempo) das estátuas - representando iconograficamente as Quatro Estações que um dia adornaram o jardim da chácara:

Era ao fundo, lado direito do pavilhão, onde antigamente havia uma clareira limitada por quatro estátuas representando as Estações. Só o Verão ainda se fazia ver de pé, e a parte inferior da Primavera, em cujo interior, como de dentro de um vaso, crescia uma vigorosa samambaia dominando os bordos

\footnotetext{
${ }^{31}$ CARDOSO. Crônica da casa assassinada, p. 40, grifos nossos.

${ }^{32}$ CARDOSO. Crônica da casa assassinada, p. 31.

${ }^{33}$ LOREDO NETA. Crônica da casa assassinada: uma poética da finitude.

${ }^{34}$ CARDOSO. Crônica da casa assassinada, p. 329, grifos nossos.
} 
partidos. $^{35}$

Essa representação funcionaria como uma marcação temporal simbólica, lembrandonos que a vida é cíclica: depois da semeadura vem a colheita, depois da alegria e da luz do verão vem a sombra e o frio do inverno. Entretanto, a “vigorosa samambaia”, refuncionalizando à quase extinta estátua da Primavera, parece apontar para um corpo estranho que nasce e toma força em um lugar que não lhe é próprio, tal como o câncer que mais tarde atingirá Nina, e que, rompendo os tecidos, acabará por destruir sua beleza e levá-la à morte. Também a estátua do Verão, a única ainda de pé, pode simbolizar que é chegado o tempo da colheita, sem considerar que os frutos poderão estar estiolados.

Uma imagem iconográfica pode remeter à outra já estabelecida através da cultura e de significado convencionado, tal como: a Pietá, de Michelangelo, o Pensador, de Rodin, e a Gioconda, de Leonardo da Vinci, entre outras representações nas artes plásticas. No romance de Lúcio Cardoso, na cena da morte de Alberto, Ana, desesperada e tentando erguê-lo, empurra-o de encontro à parede branca, onde se inscreve com sangue o desenho do corpo do rapaz. De alto teor dramático e imagético, essa cena parece transportar-nos, de imediato, à outra inscrição de dor e martírio plasmada em um tecido milenar. À lembrança de que outra dor, a qual outro jovem homem morto essa imagem nos remete? De raízes católicas, expressas em seus depoimentos e ao longo de sua obra, é a imagem do Cristo massacrado que parece perseguir o autor. A esse respeito, Ruth Silviano Brandão afirma: “é o humano que Lúcio privilegia em Cristo, a humanidade sujeita à dor e à morte, representações dramáticas da condição do homem universal visto em sua pequenez e miséria de homem pecador em busca de redenção.”36

Nina, corajosamente, desafia o estabelecido e, no intento de conhecer um pouco do que paradoxalmente orienta e oprime os irmãos, parte em direção ao passado da família. Simbolicamente soterrado no porão, esse passado está localizado, portanto, na parte baixa e nos fundos da casa e é zelado por uma negra velha, bêbada e caduca "molambo vivo de um passado arruinado”. ${ }^{37}$ Em sua incursão, ela conta com a companhia da fiel Betty. Juntas, as duas mulheres, que não pertencem à família, vão descobrir o retrato de Maria Sinhá, tia-avó dos irmãos Meneses, incompreendida e condenada ao limbo.

\footnotetext{
${ }^{35}$ CARDOSO. Crônica da casa assassinada, p. 109.

${ }^{36}$ BRANDÃO. Estes corpos humanos, como eu os amo, p. 152.

${ }^{37}$ DIMAS. Espaço e romance, p. 33.
} 
O porão, segundo Bachelard, ${ }^{38}$ representa o inconsciente, o lugar onde a racionalização é menos rápida e clara. E ele afirma:

O sonhador de porão sabe que as paredes do porão são paredes enterradas, paredes com um lado só, paredes que têm toda a terra atrás de si. E com isso o drama aumenta e o medo exagera. (...) o drama aqui é fácil demais, mas explora temores naturais, temores que estão na dupla natureza do homem e da casa. ${ }^{39}$

Obscuro e insalubre, o porão, assim descrito, parece soterrar nossas memórias sob escombros quase intransponíveis.

Ao iniciar sua descida, Nina observa que o céu sobre suas cabeças está escuro, em uma clara ameaça de chuva. Vencendo a pouca resistência da fechadura (o passado é iminente), adentra no porão "lugar úmido e escuro, encimado por enormes travas, e cheirando a mofo" 40 e, sob uma luz tênue, percebe objetos jogados aqui e ali - escolhos herdados que a família não se anima a alijar, simbolizando a bagagem psíquica que as pessoas carregam inutilmente pela vida afora - e entre esses "havia um genuflexório, com o veludo rasgado, deixando à mostra o enchimento de paina”, ${ }^{41}$ possível símbolo de uma religiosidade caduca e exposta; o inútil espelho "rachado de ponta a ponta”, ${ }^{2}$ representante provável de uma vaidade secular (e igualmente inútil) trincada e, por fim, o retrato de Maria Sinhá, que emerge do passado sob "uma densa camada de pó", ${ }^{43}$ cujos traços Nina reconhece no semblante do marido e dos cunhados como se estes trouxessem em si os vestígios indeléveis de seu passado:

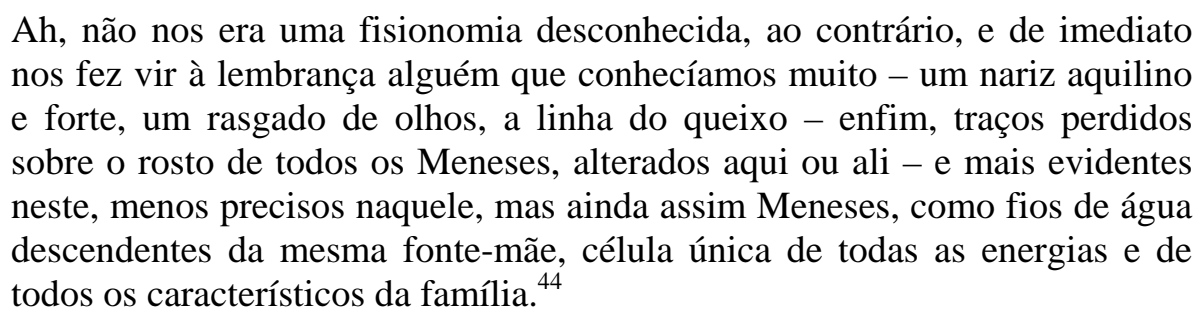

\footnotetext{
${ }^{38}$ BACHELARD. A poética do espaço.

${ }^{39}$ BACHELARD. A poética do espaço, p. 38.

${ }^{40}$ CARDOSO. Crônica da casa assassinada, p. 138-139.

${ }^{41}$ CARDOSO. Crônica da casa assassinada, p. 138.

${ }^{42}$ CARDOSO. Crônica da casa assassinada, p. 138.

${ }^{43}$ CARDOSO. Crônica da casa assassinada, p. 138.

${ }^{44}$ CARDOSO. Crônica da casa assassinada, p. 139.
} 
Embora parte inegável da família, Maria Sinhá, no entanto, foi relegada ao silêncio e ao esquecimento. Devolvendo o retrato à poeira do porão, Betty define a antepassada dos Meneses como “memória, apenas memória de um tempo que não volta mais”. ${ }^{45}$ Sobre a relação casa/memória, Bachelard conclui:

(...) não somente nossas lembranças como também nossos esquecimentos estão "alojados", nosso inconsciente está “alojado". Nossa alma é uma morada. E lembrando-nos das "casas", dos "aposentos", aprendemos a "morar" em nós mesmos. Já podemos ver que as imagens da casa caminham nos dois sentidos: estão em nós tanto quanto estamos nelas. ${ }^{46}$

Na estrutura da imagem em seu conjunto, isto é, na relação final das três mensagens reunidas em sua significação expressas no mapa, juntamente com outras imagens textuais das quais demos uma pequena amostra, o autor parece reiterar a dialética estagnação e fluidez que perpassa sua narrativa. Para Barthes, "um texto longo pode ter apenas um significado global, graças à conotação, e é esse significado que se relaciona com a imagem”. ${ }^{47}$ Essa dialética foi levantada por Antonio Candido, ${ }^{48}$ em uma análise da obra L'assommoir, de Zola (1877), que a destaca como cerne daquela narrativa.

Na tentativa de recuperar a "capacidade de enxergar o invisível”, ${ }^{49}$ que o cineasta Wim Wenders teme estar perdida, acreditamos que aquio esboço feito pelo autor, anteposto à escrita, funcionaria como uma mônada narrativa, sintetizando e antecipando o que o texto desdobrará em seguida.

Esta nos parece ser uma leitura possível dessa imagem cardosiana "la interpretación fresca y novedosa" ${ }^{50}$ de que nos fala Manguel. Tal seria "el relato que surge de una imagen". 51

\footnotetext{
${ }^{45}$ CARDOSO. Crônica da casa assassinada, p. 140.

${ }^{46}$ BACHELARD. A poética do espaço, p. 20.

${ }^{47}$ BARTHES. A retórica das imagens, p. 32.

${ }^{48}$ CANDIDO. Degradação do espaço.

${ }^{49}$ Citado por GUIMARÃES. Imagens da memória: entre o legível e o visível.

${ }^{50}$ MANGUEL. Leer imágenes. Una historia privada del arte, p. 21

${ }^{51}$ MANGUEL. Leer imágenes. Una historia privada del arte, p. 21.
} 


\section{RESUMEN}

Este artículo visa a una investigación previa del modo como se articula la configuración espacio/temporal en la novela Crônica da casa assassinada, de Lúcio Cardoso a partir de una lectura crítica de las imágenes textuales y visuales, especialmente el boceto hecho por el autor e inserto en la narrativa.

\section{PALABRAS-CLAVE}

Lúcio Cardoso, boceto, imagen, espacio, tiempo

\section{REFERÊNCIAS}

AYALA, Walmir. Lúcio pintor. O Eixo e a Roda, Belo Horizonte, v. 17, p. 173-174, jul./dez. 2008.

BACHELARD, Gaston. A poética do espaço. Trad. Antonio de Pádua Danesi. São Paulo: Martins Fontes, 2003.

BARTHES, Roland. A retórica das imagens. In: O obvio e o obtuso. Trad. Lea Novais. Rio de Janeiro: Nova Fronteira, 1990. p. 27-43.

BARTHES, Roland. A câmara clara: nota sobre a fotografia. Trad. Júlio Castañon Guimarães. Rio de Janeiro: Nova Fronteira, 1984.

BRANDÃO, Ruth Silviano. Estes corpos humanos, como eu os amo. Revista do Centro de Estudos Portugueses, Belo Horizonte, v. 28, n. 39, p. 149-159, jan./jun. 2008.

BURKE, Peter. Testemunha ocular: história e imagem. Trad. Vera Maria Xavier dos Santos, Bauru, SP: EDUSC, 2004.

CANDIDO, Antonio. Degradação do espaço. Revista de Letras, Assis-SP, v. 14, p. 7-36, 1972.

CARDOSO, Lúcio. Crônica da casa assassinada. 10. ed. Rio de Janeiro: Civilização Brasileira, 2009.

CHEVALIER, J; GHEERBRANT, A. Dicionário de símbolos. 23. ed. Trad. Vera da Costa e Silva et al. Rio de Janeiro: J. Olímpio, 2009.

DIDI-HUBERMAN, Georges. O que vemos, o que nos olha. Trad. Paulo Neves. São Paulo: Ed. 34, 1998.

DIMAS, Antonio. Espaço e romance. 3. ed. São Paulo: Ática, 1994. (Série Princípios, 23)

GUIMARÃES, César. Imagens da memória: entre o legível e o visível. Belo Horizonte: Ed. UFMG, 1997.

LOREDO NETA, Maria Madalena. Crônica da casa assassinada: uma poética da finitude. 2007. 112p. Dissertação (Mestrado em Letras - Literatura Brasileira) - Faculdade de Letras, Universidade Federal de Minas Gerais, Belo Horizonte, 2007.

MANGUEL, Alberto, Leer imágenes. Una historia privada del arte. Trad. Carlos José Restrepo. Madrid: Alianza, 2003. 
SELIGMAN-SILVA, Márcio. A escritura da memória: mostrar palavras e narrar imagens. Remate de Males, Dossiê "Literatura como arte da memória”, Campinas, v. 26, n. 1, p. 31-45, jan./jun.2006.

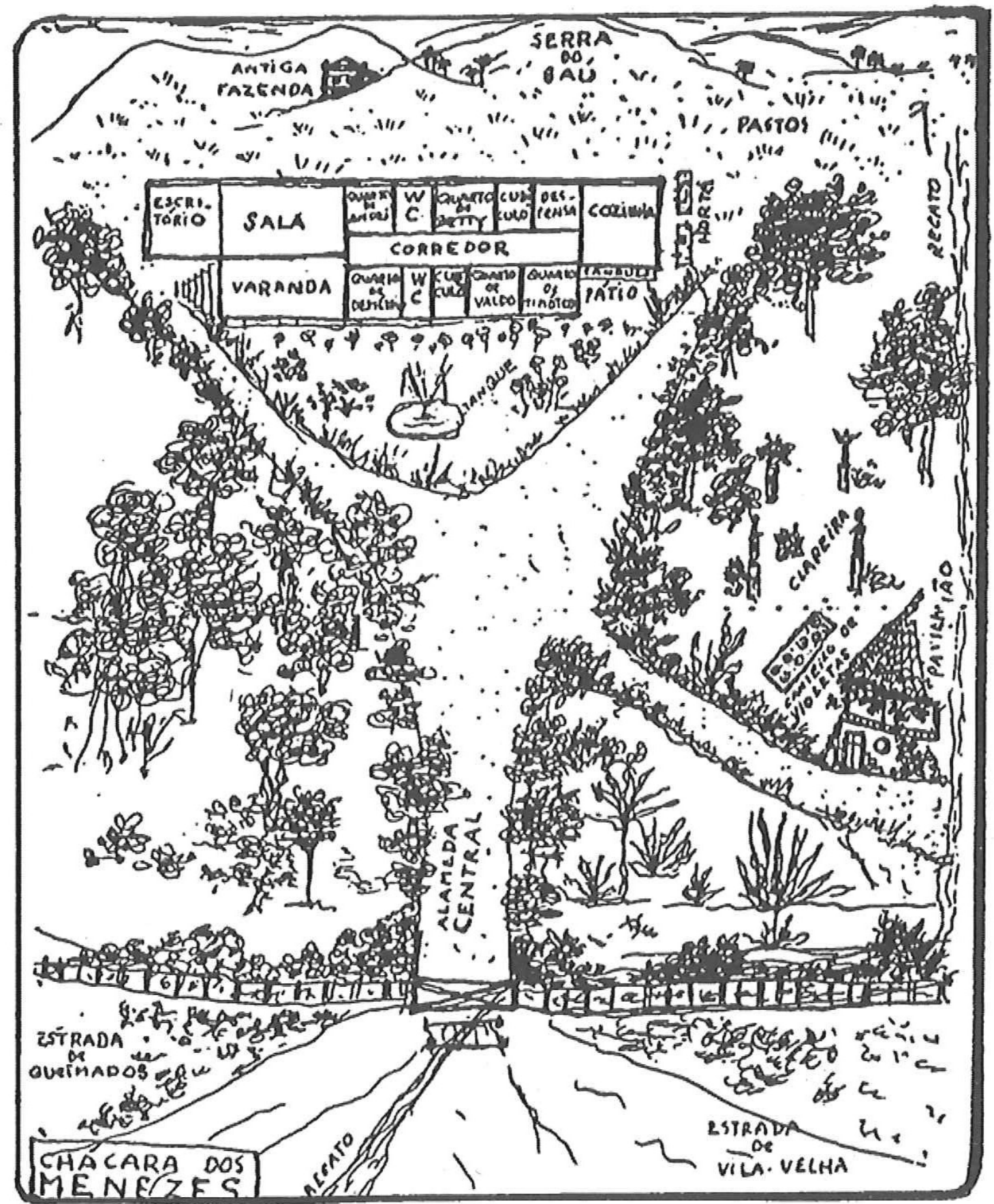

${ }^{52}$ CARDOSO. Crônica da casa assassinada, p. 18. 